\title{
Available online at http://ojs.unik-kediri.ac.id/index.php/ukarst/index

\section{Easy Way To Determine The Feasibility Of Coarse Aggregate On All Pavement Layers Using The Los Angeles Tatonas TA-700 Machine} \author{
H. D. Pramudya ${ }^{6}$ \\ 1,2*3,4,5,6 Faculty of Engineering, Kadiri University \\ Email: ${ }^{*}$ iwan candra@unik-kediri.ac.id
}

M. K. K. Ali ${ }^{1}$, A. I. Candra ${ }^{2 *}$, E. R. Purwanti ${ }^{3}$, R. W. Izzati $^{4}$, K. Y. Hutama ${ }^{5}$, M. Roziq,

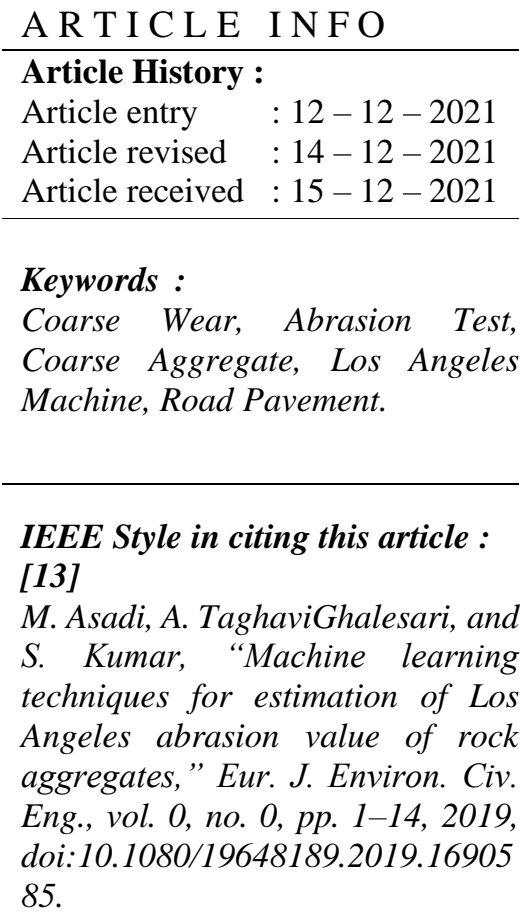

A R T I C LE IN F O

Article History :

Article entry $\quad: 12-12-2021$

Article revised : : $14-12-202$

Keywords :

Coarse Wear, Abrasion Test, Coarse Aggregate, Los Angeles Machine, Road Pavement. 85 .

\section{Introduction}

Kedak Village is one of the villages in Kediri City. This village is famous as a producer of coral or crushed stone. The coral is produced to meet the needs of coarse aggregate in Kediri and its surroundings. One of the uses of coral or crushed stone is to be used as a material in construction. Aggregates are the dominant material in the manufacture of construction materials such as road pavements [1]. In general, a mixture of pavement layers is a combination of approximately $95 \%$ of aggregate (coarse and fine aggregate), which is bonded together by an

Easy Way To Determine The Feasibility Of Coarse Aggregate On All Pavement Layers Using The Los Angeles Tatonas TA-700 Machine
The use of coarse aggregate with poor quality can cause bumpy roads, cracked roads, potholes, and others. Coarse aggregate wear is an indicator of the aggregate resistance index against friction with other objects. Any aggregate used in a pavement mix must meet the wear requirements. Low wear causes the aggregate a low level of stability. This rearch ains to determ the feasibility of coarse aggregate is reviewed based on wear with abrasion testing. This research was conducted by using an abrasion test using the Los Angeles TA-700 machine and SNI 2417:2008 as a reference. The specimens were taken at random and met the criteria for passing the number 3/4 sieve and stuck on the 2500 gram sieve number $1 / 2$, and the aggregate that passed the 1/2 sieve was stuck on the 3/8 sieve as much as 2500 grams. The results obtained stated that the average wear of the abrasion test was $26.6 \%$. Based on these results, the aggregate can be said to be feasible because it does not exceed $40 \%$ in accordance with the provisions of the 2018 Binamarga General Specifications. So that coarse aggregate from Kedak Village, Kediri can be used for all mixtures of road pavement layers. 
asphalt binder [2]. Fine aggregate consists of particles of natural sand or fine crushed stone that pass the No. $4(4.75 \mathrm{~mm})$ sieve. Meanwhile, coarse aggregate consists of crushed stone or crushed gravel retained on a No. sieve. $4(4.75 \mathrm{~mm})$ which is clean, dry, strong, and free from other irritating materials [3]. The coarse aggregate in the asphalt mixture is responsible for carrying the load imposed by the traffic on it.

The use of coarse aggregate with poor quality can cause bumpy roads, cracked roads, potholes, and roads that can not last long [4]. Because of this, the coarse aggregate used in the pavement layer must be of good quality. The quality of the aggregate in the asphalt mixture is strongly influenced by the characteristics of the aggregate particles, such as grain shape, grain size, angularity, texture, and morphological characteristics [5][6]. There are several parameters that are used as a benchmark for the feasibility of coarse aggregate, including adhesion to asphalt, flatness index, water absorption, specific gravity, and wear [7]. Coarse aggregate wear is an indicator of the aggregate resistance index against friction with other objects. Any aggregate to be used in a pavement mix must meet the wear requirements. According to the 2018 Binamarga General Specification, it is explained that coarse aggregate for a good road pavement has a wear value of not more than $40 \%$ with an abrasion test of 500 revolutions [8]. If a coarse aggregate used in a road pavement layer has a wear value of more than $40 \%$, aggregate can certainly not be able to withstand the load on it because the aggregate is easily crushed. This can cause bumpy roads, potholes, and easy damage.

Several studies regarding the observation of aggregate wear using the Los Angeles machine show that aggregate wear affects the quality of aggregate resistance [9][10]. However, there is still no aggregate feasibility study using samples from Kedak Village, Kediri.

The purpose of this study is to determine the feasibility of coarse aggregate in Kedak Village, Kediri. This research was conducted using a Los Angeles TA-700 engine with reference to SNI 2417-2008 [11]. The specimens were taken at random and met the criteria for passing the number $3 / 4$ sieve and stuck on the 2500 gram sieve number $1 / 2$, and the aggregate that passed the $1 / 2$ sieve was stuck on the $3 / 8$ sieve much as 2500 grams. From this research, it will be known the wear value of coarse aggregate originating from Kedak Village, Kediri. So, by knowing the feasibility results, it can be used as a reference for the mixture of road pavement layers.

Easy Way To Determine The Feasibility Of Coarse Aggregate On All Pavement Layers Using The Los Angeles Tatonas TA-700 


\section{Research Method}

The method used in this study is a direct experimental method on a predetermined object. This research was conducted at the Civil Engineering Laboratory, Kadiri University. To determine the wear value, an abrasion test was carried out with the Los Angeles TA-700 Machine using aggregate from Kedak Village, Kediri. Furthermore, the results obtained from the abrasion test are analyzed using the 2018 Binamarga General Specifications, and it will be concluded whether the aggregate is feasible or not as a road pavement material.

\subsection{Material}

The material used in this research is coarse aggregate as a test object and water as an object that helps clean the aggregate from dust and dirt.

\subsubsection{Coarse Aggregate}

This study uses coarse aggregate from the Kedak area, Kediri. The size of the coarse aggregate used is the aggregate that passes the sieve no. $3 / 4$ and stuck to filter no. $1 / 2$ as much as 2500 grams, and the aggregate passes sieve no. $1 / 2$ and retained filter no. $3 / 8$ as much as 2500 grams [12].

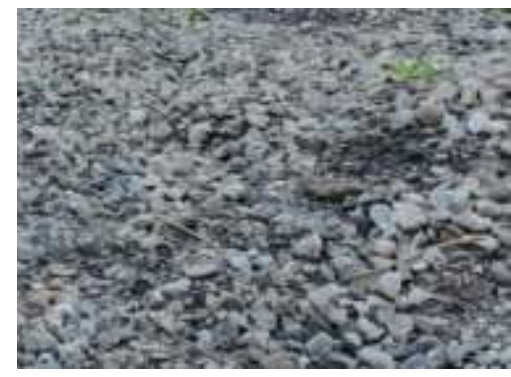

Source: Personal Documentation

Figure 1. Coarse Aggregate.

\subsubsection{Water}

Clean water was used to wash aggregates before abrasion testing. This water comes from the Civil Engineering Laboratory of Kadiri University.

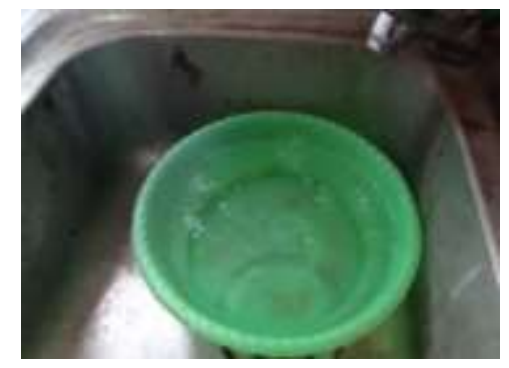

Source: Personal Documentation

Figure 2. Water.

Easy Way To Determine The Feasibility Of Coarse Aggregate On All Pavement Layers Using The Los Angeles Tatonas TA-700 Machine 


\section{$2.2 \quad$ Tool Research}

\subsubsection{Los Angeles Tatonas Abrasion Machine TA-700}

The engine consists of steel cylinders enclosed on both sides with an inner diameter of $711 \mathrm{~mm}$ (28 inches) and an inner length of $508 \mathrm{~mm}$ (20 inches). The cylinder rests on two short, discontinuous shafts and rotates horizontally. Perforated cylinder for inserting the test object. The manhole cover is securely fastened so that the inner surface of the cylinder is not disturbed. Inside the cylinder is a full $89 \mathrm{~mm}$ (3.5 inch) cross-section steel blade [13].
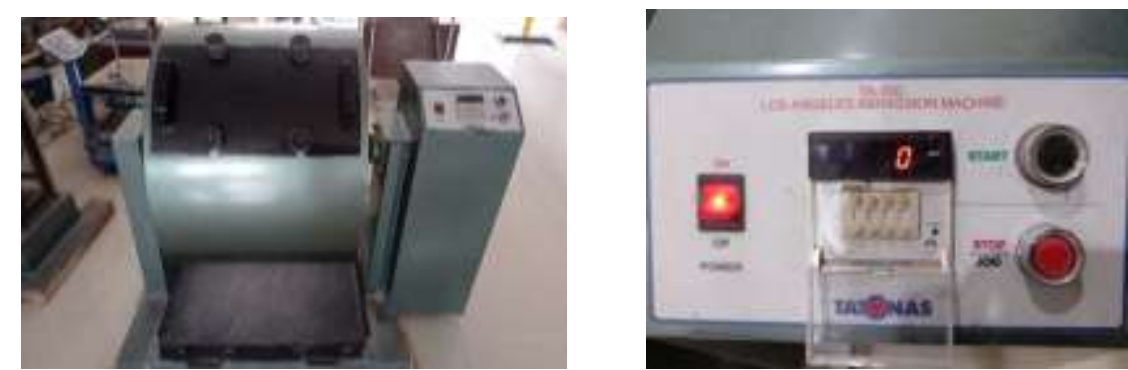

Source: Personal Documentation

Figure 3. Los Angeles Tatonas Abrasion Machine TA-700.

The Los Angeles Machine is equipped with several other equipments as follows.

- Steel Ball

The steel balls used in this study had an average diameter of $4.68 \mathrm{~cm}(127 / 32$ inches) and weighed between 390 grams and 445 grams each [4].
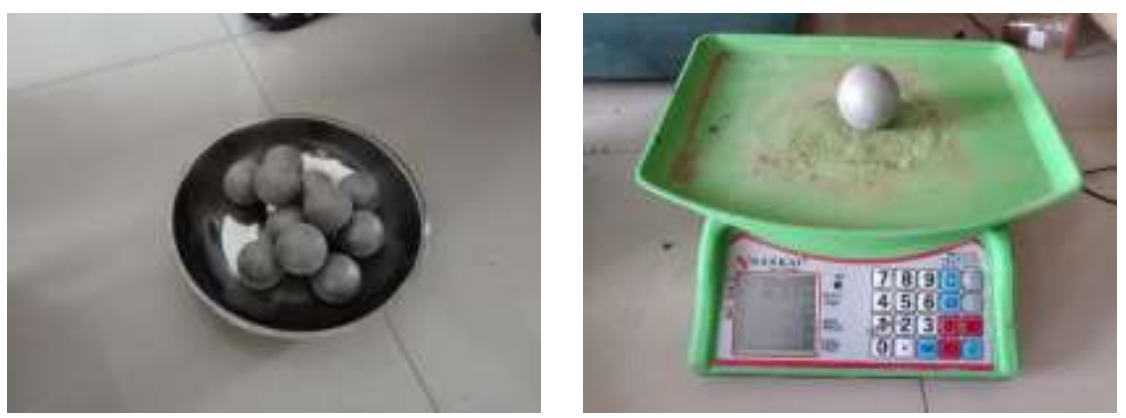

Source: Personal Documentation

Figure 4. Steel Balls.

- Pan

The baking sheet used in this study has a square shape with a length and width of $65 \mathrm{~cm}$.

This pan is used to accommodate the results of aggregate testing after abrasion tests have been carried out using a Los Angeles machine.

Easy Way To Determine The Feasibility Of Coarse Aggregate On All Pavement Layers Using The Los Angeles Tatonas TA-700 


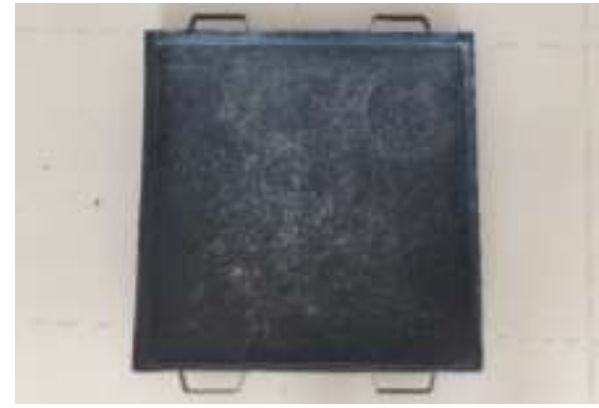

Source: Personal Documentation

Figure 5. Pan.

\subsubsection{Sieve}

Sieve numbers $3 / 4,1 / 2,3 / 8$ were used to prepare aggregates before the Abrasion test was carried out. And sieve number 12 is used to sieve the aggregate after the abrasion test is carried out [14].

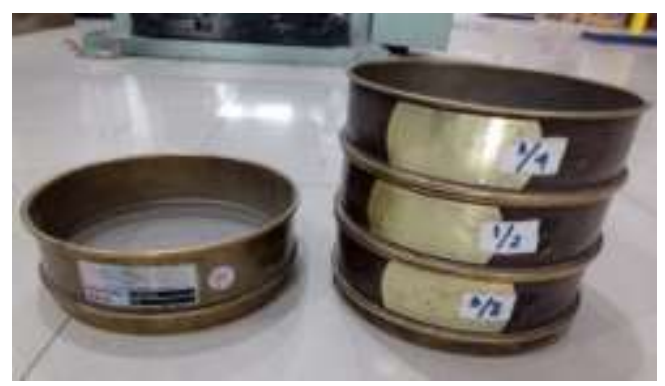

Source: Personal Documentation

Figure 6. Sieve Numbers 3/4, 1/2, 3/8, and 12.

\subsubsection{Sieve Shaker Tatonas TA-517}

Sieve Shaker is used to separate aggregates with different grain sizes [15]. Sieve Shaker is used to sieve the aggregate to be used for abrasion testing.

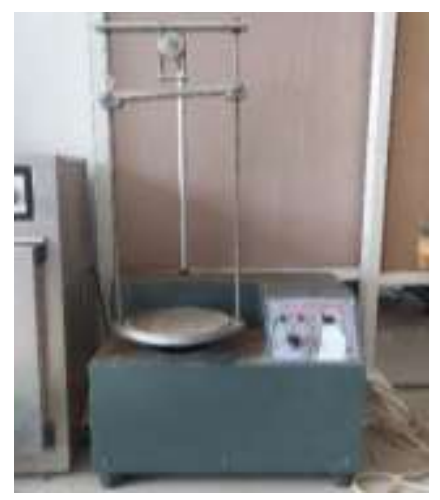

Source: Personal Documentation

Figure 7. Sieve Shaker.

Easy Way To Determine The Feasibility Of Coarse Aggregate On All Pavement Layers Using The Los Angeles Tatonas TA-700 Machine 


\subsubsection{Balance}

The scales used have an accuracy of $0.1 \%$ of the sample weight or 5 grams [16]. Scales are used to weigh aggregates before and after abrasion testing.

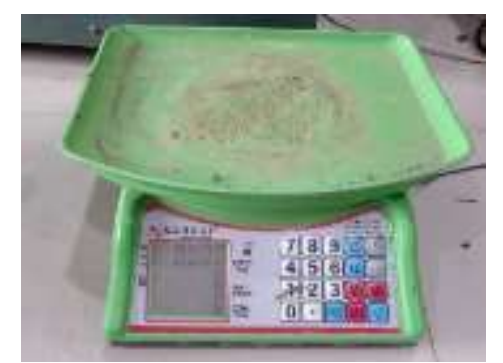

Source: Personal Documentation

Figure 8. Balance.

\subsubsection{Oven}

The oven used has a temperature control of heating up to $110^{\circ} \mathrm{C} \pm 5^{\circ} \mathrm{C}$ [17]. The oven is used to dry the aggregate until the moisture content of an aggregate becomes 0 .

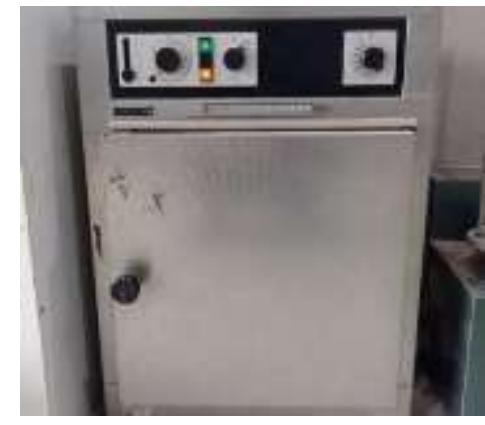

\section{Source: Personal Documentation}

Figure 9. Oven.

\subsection{Research Implementation}

The implementation of the abrasion test is carried out as follows.

1. The aggregate to be tested is prepared by taking it randomly from Kedak Village, Kediri, for abrasion testing [18].

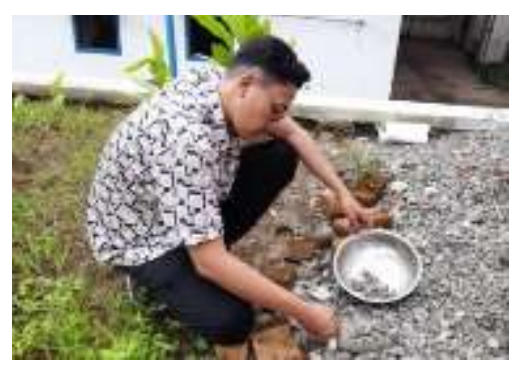

Source: Personal Documentation

Figure 10. Random Aggregate Picking.

Easy Way To Determine The Feasibility Of Coarse Aggregate On All Pavement Layers Using The Los Angeles Tatonas TA-700 Machine 
2. Wash the aggregate sample using clean water until there is no dust or mud adhering [19].

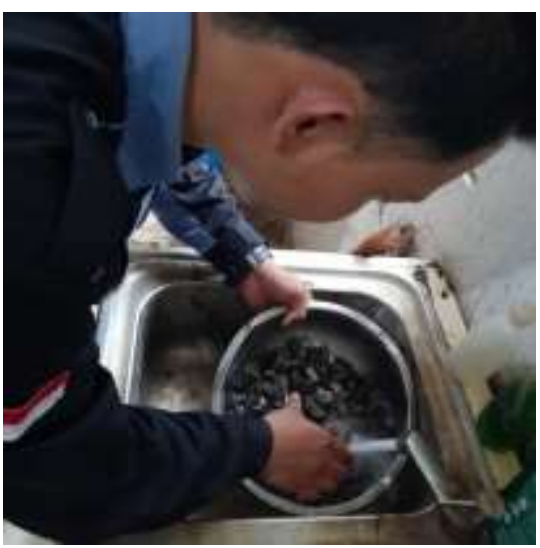

Source: Personal Documentation

Figure 11. Aggregate Wash.

3. Dry the aggregate sample using an oven at a temperature of $110^{\circ} \mathrm{C} \pm 5^{\circ} \mathrm{C}$ for 24 hours [20].

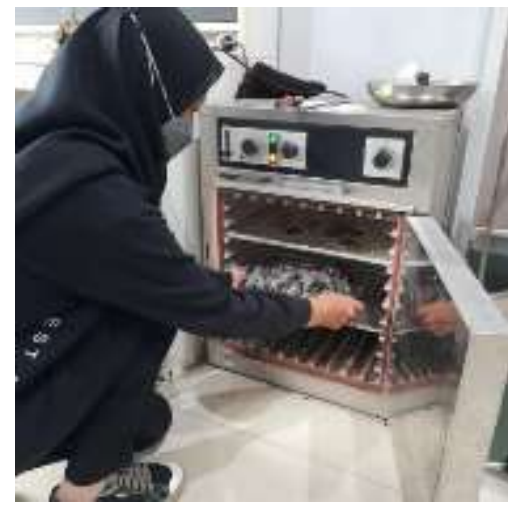

Source: Personal Documentation

Figure 12. Aggregate Drying.

4. Aggregate was sieved using a sieve shaker, with sieves numbered $3 / 4,1 / 2$, and $3 / 8$ arranged by sieve from the largest to the smallest diameter.

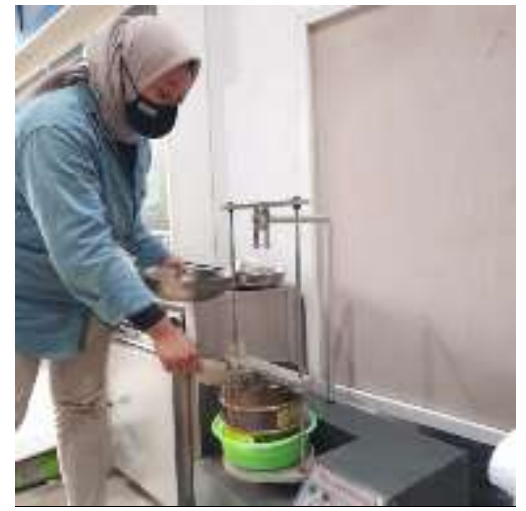

Source: Personal Documentation

Figure 13. Aggregate Sifting.

Easy Way To Determine The Feasibility Of Coarse Aggregate On All Pavement Layers Using The Los Angeles Tatonas TA-700 Machine 
5. Take the aggregate stuck in sieves number $1 / 2$ and $3 / 8$, then weigh 2500 grams each two times [21].
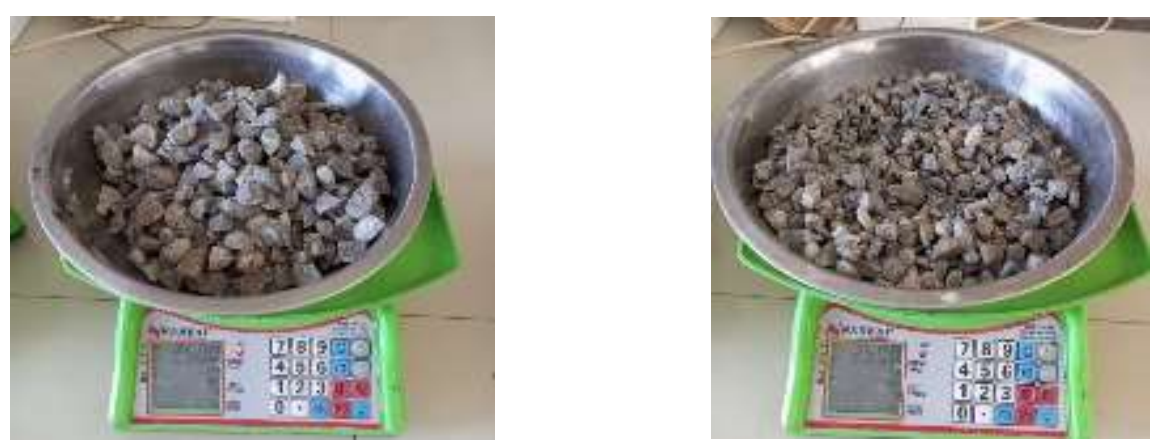

Source: Personal Documentation

Figure 14. Aggregate Weighing.

6. Mix the suspended aggregate in sieves number $1 / 2$ and $3 / 8$ that have been weighed until evenly mixed.

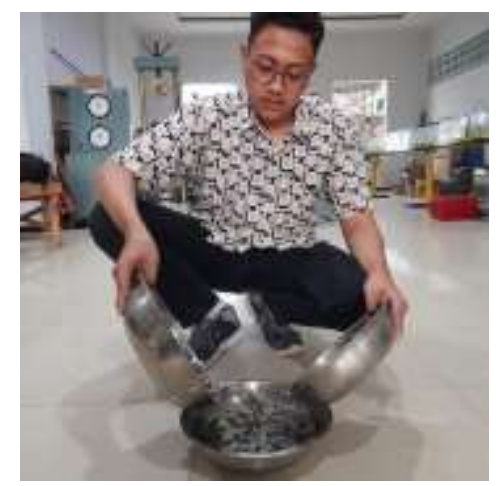

Source: Personal Documentation

Figure 15. Aggregate Mixer.

7. Put in the aggregate after weighing into the Los Angeles machine.

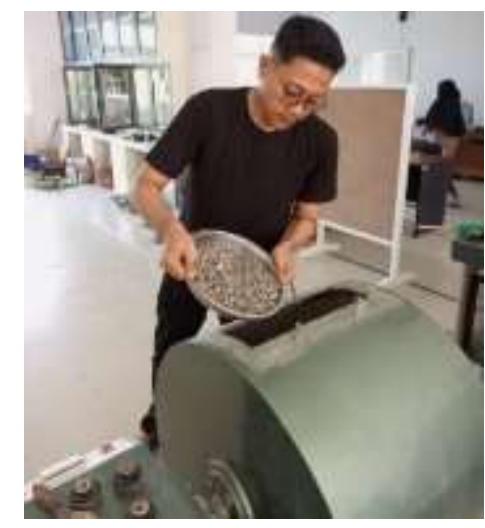

Source: Personal Documentation

Figure 16. Aggregate Loaded into Los Angeles Machine 
8. Load 12 steel balls into the Los Angeles machine [22].

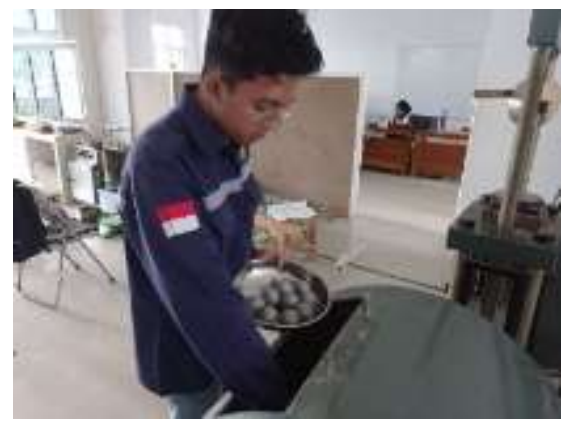

Source: Personal Documentation

Figure 17. Steel Ball Loaded into Los Angeles Machine.

9. Set the Los Angeles engine to 500 revolutions, then start it [23].

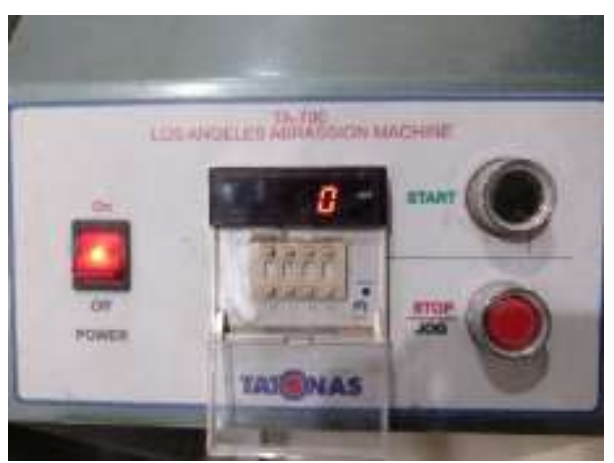

Source: Personal Documentation

Figure 18. Setting the Los Angeles Machine 500 revolutions.

10. After the Los Angeles engine reaches 500 revolutions and stops, remove the aggregate sample along with the steel ball and pour it into the tin.

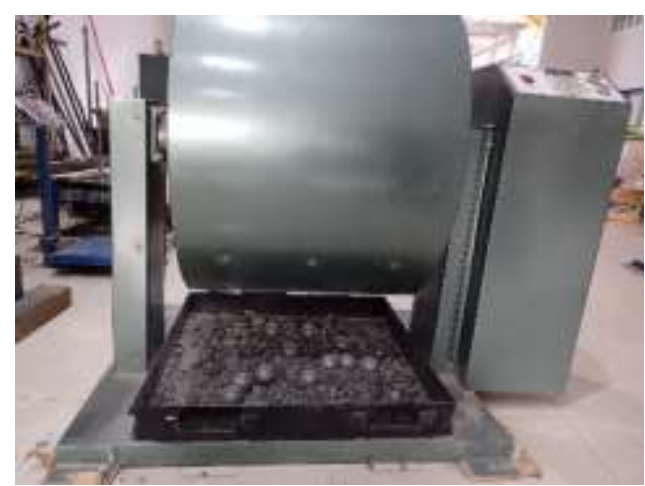

Source: Personal Documentation

Figure 19. Aggregate Removed from Los Angeles Machine. 
11. Sift the aggregate sample from the abrasion test using sieve number 12 [24].

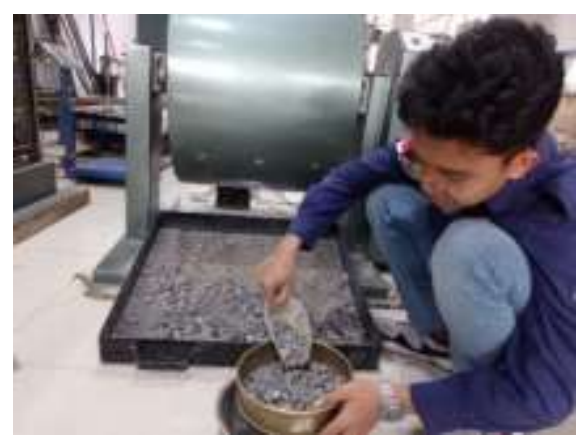

Source: Personal Documentation

Figure 20. Aggregate Sifting After Abrasion Test.

12. Wash the aggregate retained on the number 12 sieve using clean water until no dust and mud adhere to it.

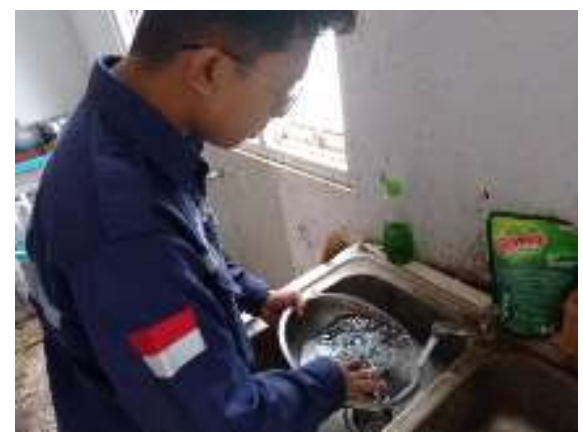

Source: Personal Documentation

Figure 21. Aggregate Wash.

13. Dry the aggregate using an oven at a temperature of $110^{\circ} \mathrm{C} \pm 5^{\circ} \mathrm{C}$ for 24 hours.

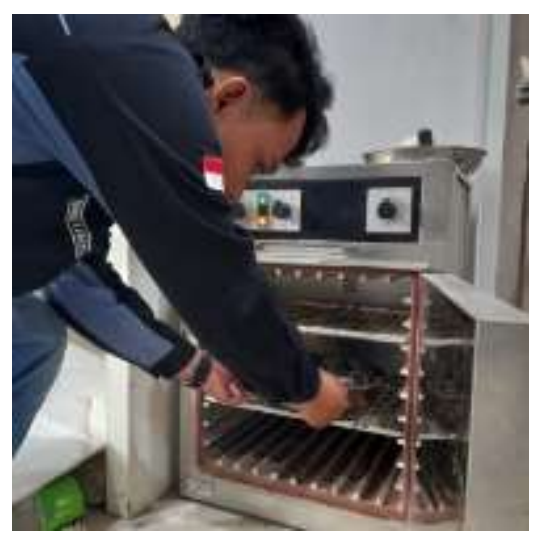

Source: Personal Documentation

Figure 22. Aggregate Drying. 
14. Weigh the abraded aggregate after drying in the oven.

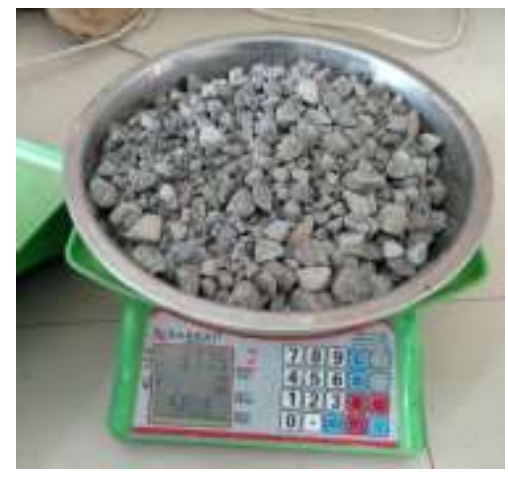

Source: Personal Documentation

Figure 23. Aggregate Weighing After Abrasion Test

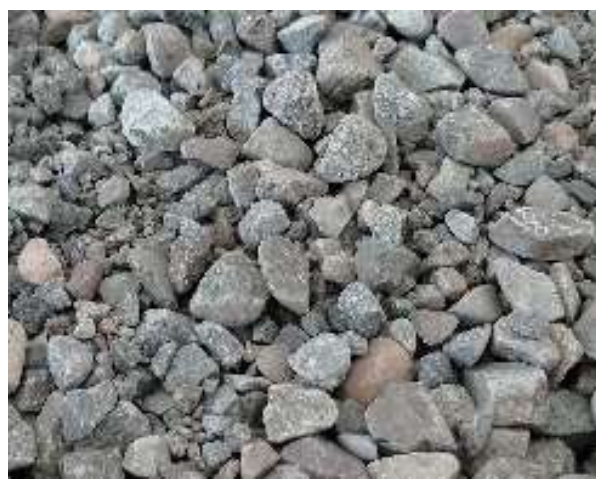

Source: Personal Documentation

Figure 24. Aggregate After Abrasion Test

\subsection{Aggregate Wear}

Aggregate wear in aggregate resistance to friction with other objects [25]. The calculation of aggregate wear is as follows.

Wear $=\frac{a-b}{a} \times 100 \%$

With Description:

a $\quad=$ Test Object Weight (grams)

$\mathrm{b} \quad=$ Weight of Retained Test Object Sieve No. $12(1.7 \mathrm{~mm})$ after the test object is inserted Los Angeles machine (grams)

According to the General Specifications of the 2018 Binamarga Division 6 [8], the provisions for the aggregate wear value can be seen in the following table.

Table 1. Coarse Aggregate Wear Condition

\begin{tabular}{ccccc}
\hline & \multicolumn{2}{c}{ Test } & Test Method & Value \\
\hline & A mix of Modified AC & 100 Revolutions & & Maks. 6\% \\
$\begin{array}{c}\text { Abrasion } \\
\text { with Los }\end{array}$ & and SMA & 500 Revolutions & SNI 2417:2008 & Maks. 30\% \\
$\begin{array}{c}\text { Angeles } \\
\text { Machines }\end{array}$ & $\begin{array}{c}\text { All kinds of another } \\
\text { graded asphalt mix }\end{array}$ & 100 Revolutions & 500 Revolutions & Maks. 8\% \\
& & Maks. 40\% \\
\hline
\end{tabular}

Source: General Specifications of Binamrga 2018

This study was used for all asphalt mixtures and used a Los Angeles engine with 500 revolutions. Therefore, the wear yield of coarse aggregate should not exceed $40 \%$.

Easy Way To Determine The Feasibility Of Coarse Aggregate On All Pavement Layers Using The Los Angeles Tatonas TA-700 Machine 


\section{Results and Discussions}

From the abrasion test carried out, the following results were obtained.

Table 1. Abrasion Test Results Samples 1 and 2

\begin{tabular}{cccc}
\hline \multicolumn{2}{c}{$\begin{array}{c}\text { Gradation Inspection } \\
\text { Sieve Size }\end{array}$} & $\begin{array}{c}\text { Number of Spins }=500 \text { Revolutions } \\
\text { Sample 1 }\end{array}$ & $\begin{array}{c}\text { Sample 2 } \\
\text { Weight (a) }\end{array}$ \\
\hline Slip & Stuck & Weight (a) & 2500 \\
$19,1\left(3 / 4^{\prime \prime}\right)$ & $12,7\left(0,5^{\prime \prime}\right)$ & 2500 & 2500 \\
$12,7\left(0,5^{\prime \prime}\right)$ & $9,52\left(3 / 8^{\prime \prime}\right)$ & 2500 & 5000 \\
& Total Weight & 5000 & 3565 \\
\hline
\end{tabular}

Source: Research Results

Based on the table above, it can be seen that the data from the abrasion test results.

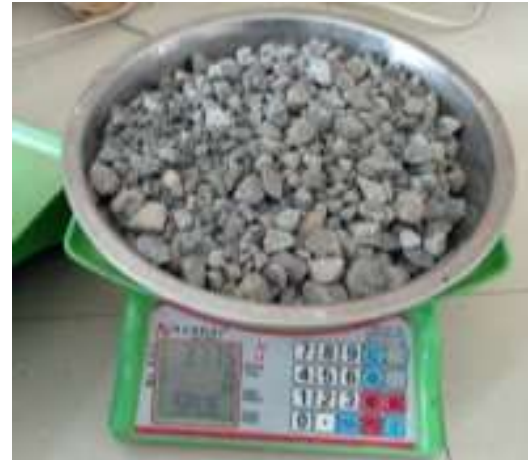

Source: Personal Documentation

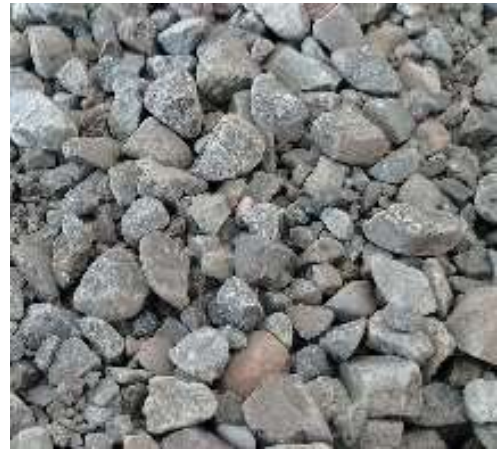

Source: Personal Documentation

Figure 25. Sample Abrasion Test

Figure 26. Sample Details Aggregate 1

Results 1

Based on Figure 25. it can be seen that the weight of the aggregate retained on sieve number 12 after the abrasion test was carried out on sample 1, the result was 3775 grams.

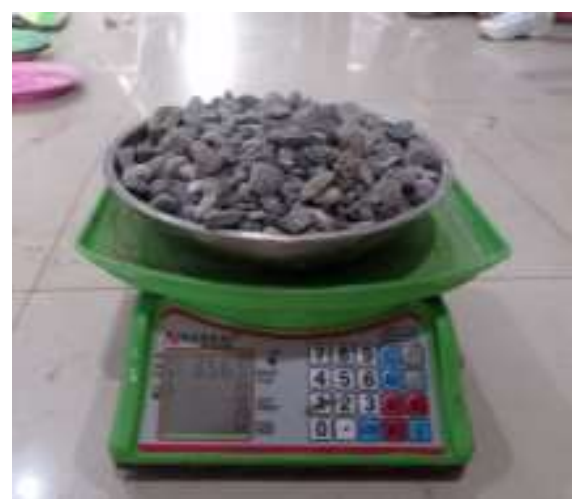

Source: Personal Documentation

Figure 27. Sample Abrasion Test

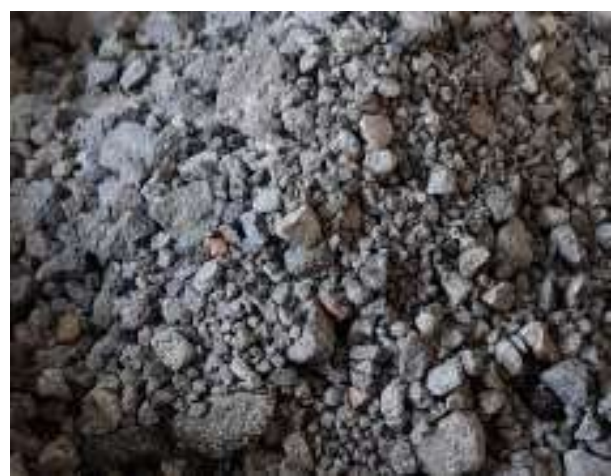

Source: Personal Documentation

Figure 28. Sample Details Aggregate 2

Results 2

Easy Way To Determine The Feasibility Of Coarse Aggregate On All Pavement Layers Using The Los Angeles Tatonas TA-700 
Based on Figure 27. it can be seen that the weight of the aggregate retained on sieve number 12 after the abrasion test was carried out on sample 2, the result was 3565 grams.

From the data above, aggregate wear can be calculated as follows.

Aggregate $1=\frac{5000-3775}{5000} \times 100 \%=24,5 \%$

Aggregate $2=\frac{5000-3565}{5000} \times 100 \%=28,7 \%$

From the calculation of aggregate wear results, it is stated that in sample 1, it is $24.5 \%$, and in sample 2, it is $28.7 \%$. Furthermore, the average wear of the aggregate can be calculated as follows.

Average Wear $=\frac{24,5+28,7}{2}=26,6 \%$

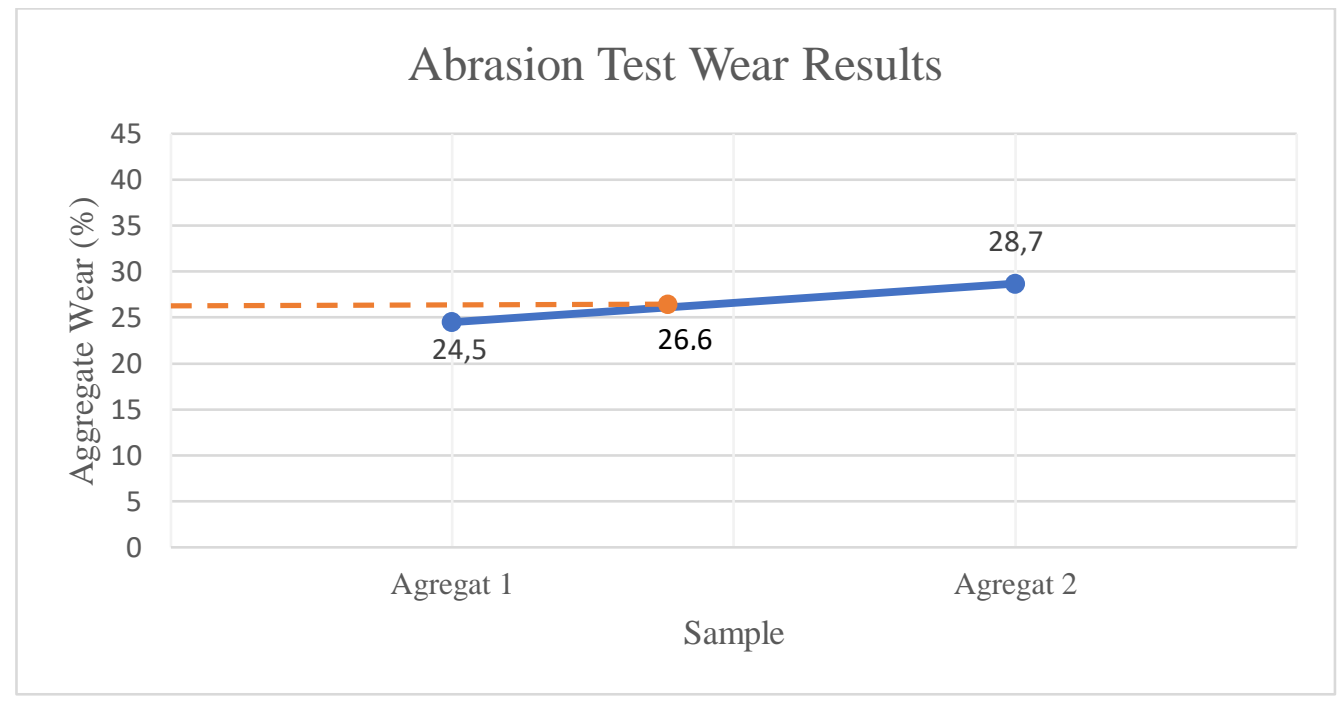

Source: Research Results

Figure 29. Abrasion Test Wear Results.

The calculation of the average wear and tear obtained a value of $26.6 \%$. According to the Binamarga General Specifications 2018, division 6 states that the aggregate to be used for asphalt mixtures must not exceed $40 \%$. So based on the results of the abrasion test, it can be concluded that the aggregate is declared feasible for asphalt mixture materials.

\section{Conclusion}

Based on the research that has been done, the average wear result of the abrasion test is $26.6 \%$, so that the aggregate can be declared feasible for all road pavement mix materials.

\section{Acknowledgments}

Researchers support Kadiri University, especially the Faculty of Engineering, which has allowed to conduct research and prepare reports.

Easy Way To Determine The Feasibility Of Coarse Aggregate On All Pavement Layers Using The Los Angeles Tatonas TA-700 Machine 


\section{Bibliography}

[1] M. Díaz-Piloneta, M. Terrados-Cristos, J. V. Álvarez-Cabal, and E. Vergara-González, "Comprehensive analysis of steel slag as aggregate for road construction: Experimental testing and environmental impact assessment," Materials (Basel)., vol. 14, no. 13, 2021, doi: 10.3390/ma14133587.

[2] M. R. Pouranian, M. Shishehbor, and J. E. Haddock, "Impact of the coarse aggregate shape parameters on compaction characteristics of asphalt mixtures," Powder Technol., vol. 363, pp. 369-386, 2020, doi: 10.1016/j.powtec.2020.01.014.

[3] K. P. Umum, "Pedoman Bahan Konstruksi Bangunan dan Rekayasa Sipil (Pd 05 - 2018 - B)," Kementrian Pekerj. Umum dan Perumah. Rakyat, no. September, 2019.

[4] A. A. A. H. Mohamed K. Ismail and Mohamed Lachemi, "Effect of Fiber Type on Impact and Abrasion Resistance of Engineered Cementitious Composite," ACI Mater. J., vol. 115, no. 6, 2018, doi: 10.14359/51710960.

[5] J. Gao, H. Wang, Y. Bu, Z. You, M. R. M. Hasan, and M. Irfan, "Effects of coarse aggregate angularity on the microstructure of asphalt mixture," Constr. Build. Mater., vol. 183, pp. 472-484, 2018, doi: 10.1016/j.conbuildmat.2018.06.170.

[6] X. Ding, T. Ma, and W. Gao, "Morphological characterization and mechanical analysis for coarse aggregate skeleton of asphalt mixture based on discrete-element modeling,"

Constr. Build. Mater., vol. 154, pp. 1048-1061, 2017, doi: 10.1016/j.conbuildmat.2017.08.008.

[7] Badan Standardisasi Nasional, "Tata Cara Pelaksanaan Lapis Aspal Beton Untuk Jalan Raya (SNI 03-1737-1989)," Badan Stand. Nas. Indones., 1989.

[8] Kementerian Pekerjaan Umum dan Perumahan Rakyat, "Spesifikasi Umum 2018," Dirjen Bina Marga Nomor, 2018.

[9] L. M. Nicula, O. Corbu, and M. Iliescu, "The Influence of Blast Furnace Slag on Abrasion Resistance for Road Concretes," IOP Conf. Ser. Mater. Sci. Eng., vol. 877, no. 1, 2020, doi: 10.1088/1757-899X/877/1/012040.

[10] B. Panda, N. T. Imran, and K. Samal, "A Study on Replacement of Coarse Aggregate with Recycled Concrete Aggregate (RCA) in Road Construction BT - Recent Developments in Sustainable Infrastructure," in Recent Developments in Sustainable Infrastructure, 2021, pp. 1097-1106.

[11] B. S. Nasional, "Cara uji keausan agregat dengan mesin abrasi Los Angeles SNI 2417 2008," Badan Stand. Nas. Indones., 2008.

[12] E. Tugrul Tunc and K. Esat Alyamac, "A preliminary estimation method of Los Angeles abrasion value of concrete aggregates," Constr. Build. Mater., vol. 222, pp. 437-446, 2019, doi: 10.1016/j.conbuildmat.2019.06.176.

[13] M. Asadi, A. TaghaviGhalesari, and S. Kumar, "Machine learning techniques for estimation of Los Angeles abrasion value of rock aggregates," Eur. J. Environ. Civ. Eng., pp. 1-14, 2019, doi: 10.1080/19648189.2019.1690585.

[14] Y. Guo, V. Markine, J. Song, and G. Jing, "Ballast degradation: Effect of particle size and shape using Los Angeles Abrasion test and image analysis," Constr. Build. Mater., vol. 169, pp. 414-424, 2018, doi: 10.1016/j.conbuildmat.2018.02.170.

[15] S. A. EL-Sayed and M. E. Mostafa, "Analysis of Grain Size Statistic and Particle Size Distribution of Biomass Powders," Waste and Biomass Valorization, vol. 5, no. 6, pp. 1005-1018, 2014, doi: 10.1007/s12649-014-9308-5.

Easy Way To Determine The Feasibility Of Coarse Aggregate On All Pavement Layers Using The Los Angeles Tatonas TA-700 Machine 
[16] T. Umar, C. Egbu, and M. Saidani, "A Modified Method for Los Angeles Abrasion Test," Iran. J. Sci. Technol. - Trans. Civ. Eng., vol. 44, no. 3, pp. 941-947, 2020, doi: 10.1007/s40996-019-00268-w.

[17] A. D. Nataadmadja, O. Setyandito, E. Prahara, and I. Riyanti, "Assessing the moisture susceptibility of aggregates with Los Angeles abrasion test," AIP Conf. Proc., vol. 1903, 2017, doi: 10.1063/1.5011515.

[18] K. C. Budi, A. I. Candra, D. A. Karisma, S. Muslimin, and Sudjati, "Pengaruh Metode Perawatan Beton Dengan Suhu Normal Terhadap Kuat Tekan Beton Mutu Tinggi," J. CIVILA, vol. 5, no. 2, pp. 460-467, 2020, doi: 10.21063/jts.2020.v702.05.

[19] S. Zhang, J. Pei, R. Li, Y. Wen, and J. Zhang, "Investigation on comparison of morphological characteristics of various coarse aggregates before and after abrasion test," Materials (Basel)., vol. 13, no. 2, 2020, doi: 10.3390/ma13020492.

[20] A. Teymen, "Estimation of Los Angeles abrasion resistance of igneous rocks from mechanical aggregate properties," Bull. Eng. Geol. Environ., vol. 78, no. 2, pp. 837-846, 2019, doi: 10.1007/s10064-017-1134-0.

[21] A. Mohajerani, B. T. Nguyen, Y. Tanriverdi, and K. Chandrawanka, "A new practical method for determining the LA abrasion value for aggregates," Soils Found., vol. 57, no. 5, pp. 840-848, 2017, doi: 10.1016/j.sandf.2017.08.013.

[22] X. Bian, K. Shi, W. Li, X. Luo, E. Tutumluer, and Y. Chen, "Quantification of Railway Ballast Degradation by Abrasion Testing and Computer-Aided Morphology Analysis," J. Mater. Civ. Eng., vol. 33, no. 1, p. 04020411, 2021, doi: 10.1061/(asce)mt.19435533.0003519.

[23] S. Ahmad, M. Maslehuddin, M. Shameem, R. M. Faysal, and S. K. Adekunle, "Effect of abrasion and chemical treatment of recycled aggregate on the workability, strength, and durability properties of concrete," Eur. J. Environ. Civ. Eng., pp. 1-16, 2020, doi: 10.1080/19648189.2020.1797886.

[24] R. Ajalloeian and M. Kamani, "An investigation of the relationship between Los Angeles abrasion loss and rock texture for carbonate aggregates," Bull. Eng. Geol. Environ., vol. 78, no. 3, pp. 1555-1563, 2019, doi: 10.1007/s10064-017-1209-y.

[25] J. Wu, L. Wang, Y. Hou, Z. Qian, L. Meng, and Q. Zhao, "Simulation on the MicroDeval test for the aggregate wear properties measurement," Constr. Build. Mater., vol. 180, pp. 445-454, 2018, doi: 10.1016/j.conbuildmat.2018.03.264. 